Marketing and Branding Research

WWW.CIKD.CA

\title{
Crude Oil Price, Urbanization and Environmental Pollution: Fresh Evidence from Selected African OPEC Member Countries
}

\author{
Kabiru Saidu Musa ${ }^{1^{*}}$, Rabiu Maijama'a ${ }^{2}$ \\ ${ }^{1}$ Department of Economics, Faculty of Social and Management Sciences, Bauchi State University Gadau, Yuli \\ Campus, Bauchi-Nigeria \\ ${ }^{2}$ Nigerian National Petroleum Corporation, NNPC Towers, Central Business District, Garki, Abuja-Nigeria
}

\section{Keywords: \\ Crude oil price, Urbanization, Environmental pollution, African OPEC countries, Panel ARDL}

Received

03 December 2020

Received in revised form

13 December 2020

Accepted

13 December 2020

*Correspondence:

Kabirusaidumusa@gmail.com

\begin{abstract}
The paper investigates the effect of crude oil price and urbanization on the environmental pollution in the case of six selected OPEC African member countries for the 1986-2018 period and applied panel ARDL model. Finding from PMG model indicates that crude oil price, urbanization and foreign direct investment have a significant negative influence on environmental pollution in the long-run while in the short-run, urbanization has a significant negative impact on environmental pollution but all the remaining variables have a significant positive impact on environmental pollution. There was slow speed of adjustment from short-run disequilibrium to equilibrium position at 26 percent yearly. The Pairwise Dumitrescu Hurlin panel causality test revealed the existence of bilateral causality flowing from urbanization to environmental pollution, economic growth to environmental pollution, economic growth to crude oil price and economic growth to urbanization. While unidirectional causality exists flowing from crude oil price to environmental pollution and foreign direct investment to economic growth. As a recommendation for these countries to achieve and maintain quality environment, the nations must restrict the speed of urbanization process to its optimum level and this process will decrease the environmental effects associated with it. The existence of exertions regarding development and urbanization, now it is the right time for the governments of these countries to produce and stretch plan that will continue to concentrate on exploration of crude oil, since the increasing crude oil price from the global energy market exerts positive effect on the entire revenue generated by these economies.
\end{abstract}


Growth of the economy together with urban population have greater part to play in the country's environment and $\mathrm{CO}_{2}$ emissions condition. The knowledge that urban population causing $\mathrm{CO}_{2}$ emissions can be verified via numerous motives, but the only clear correlations is through consumption of energy largely because of the concentration of population in the urban areas (Mahmood et al., 2020). One of the greatest and the most vital purposes of millennium development goals rests on the provision of tidy environment to the entire mankind due to the benefit of clean and modern technologies and if this is not achieved, then technologies that promote the emission of pollution would be dangerous for the entire universe in form of pollution and consequently result in the cease of long-run communities' welfare (Claessens \& Feijen, 2007; Mahmood, 2020). Therefore, petroleum sector should flock back the oil money in maintaining the environmental quality and the population checking measures by countries should also be strengthen or else, ignoring these two phenomena would bring about pollution and environmental degradation which will lead to the achievement of unsustainable development in the universe at large. The relationship between crude oil price and urbanization on the environmental pollution has attracted attention from both the academia and professional environments. A strong connection between these three variables would have a significant implication regarding the quality of the environment because crude oil exploration activities and increase in the number of urban populations are correlated with environmental pollution and therefore affecting the goal of achieving sustainable environment. The OPEC member countries are well known for their crude oil explorations and exports. These exploration actions and the activities of mankind such as deforestation, mining and others are causing environmental degradation.

There is an evolvement of examination for the influence of crude oil price and urbanization on environmental pollution over a given period of time. While some studies examined the causal relationship between crude oil price, urbanization and environmental pollution, but some were trying to differentiate the long run influence from the short run influence through conducting the long run equilibrium between the three variables. For instances, Mahmood et al. (2020) more recently applied ARDL approach to study the influence of crude oil price and urbanization on the level of environmental pollution of Saudi Arabia using times series data for the period of 1980 to 2014. The results revealed that rising urban population and crude oil prices have a significant long run positive influence on the level of the country's environmental pollution. In case of Nigeria, Maijama'a and Musa (2020) revealed that increasing urban population is responsible for the environmental pollution but crude oil price and foreign direct investment inflows have significant negative influence on the level of environmental pollution in the long run. While in the short run, urbanization and crude oil price are associated with environmental pollution using ARDL approach on the time series data for the 1981-2016 periods. Musa and Maijama'a (2020) in their examination for the impacts of economic growth and consumption of energy on environmental pollution for the period spanning 1981 to 2014 utilized ARDL approach and indicated that consumption of energy and economic growth were responsible for the increasing level of country's environmental pollution while crude oil price from the global energy market is associated with decreasing level of environmental pollution for both the short run and the long run period respectively. This led the authors to recommend for the consumption of energy from renewable sources in the quest of achieving environmentally friendly. Similarly, Mahmood et al. (2019) reported that trade openness, financial market development and foreign direct investment have solid effect on $\mathrm{CO}_{2}$ emissions per capita and the spillover effects of trade openness, financial market development and foreign direct 
investment remained confirmed and quantified that country's foreign trade proceedings affect the nation's environmental quality and the neighboring nations for the period spanning 1991-2014 using the case of nations in East Asia. Thus, confirming the existence of Environmental Kuznets Curve (EKC) in the region with evidence, the development of financial market seems to affect country's environmental profile which led to environmental degradation.

Therefore, on the basis of this background, our study will offer some supports in terms of balancing other studies carried out on the identical areas in the case of six selected African OPEC member countries as the outcomes of this investigation will be of help to these countries in the areas of policy making regarding their energy sectors and sustaining balance between the growth of these economies and their environments. Also, this study seeks to certify that zero errors passed via the cracks which may bounces back with negative hit to the economies of these nations.

\section{Review of Literature}

Examining the influence of crude oil price on the rate of exchange for the 1983-2017 periods in the case of Nigerian economy, Musa et al. (2020) utilized a method of ARDL and the outcome revealed that the rate of exchange was affected negatively in both the short run and the long run periods whereas economic growth and revenue from oil had a significant direct influence on the rate of exchange. With the aid of VECM approach analysis for the 1991-2018 period, Maijama'a and Musa (2020) studied the influence of fluctuation in crude oil price on unemployment in the case of Nigerian economy and their analysis indicate that both population and economic growth have a significant positive connection with unemployment but electricity consumption and crude oil price exerts a significant negative impact on unemployment in the long run with population growth being the only significant series in influencing unemployment. Again, there is unidirectional causality between population growth and unemployment, population growth to economic growth, crude oil price and population growth, crude oil price and economic growth, electricity consumption and economic growth while variance decomposition indicates that population growth responded highly to shocks in unemployment whereas impulse response function revealed that unemployment responded positively to shocks in economic growth and crude oil price while negatively to population growth and electricity consumption. Again, in the same case study and applied the same ARDL approach, Musa et al. (2019) showed that crude oil price and rate of exchange have a significant positive connection with economic growth in both the short run long run time, in their investigation for the influence of crude oil price and the rate of exchange on economic growth. Ssali et al. (2019) reported that there exists bilateral causality flowing from the use of energy to $\mathrm{CO}_{2}$ emission in the short run case while one-way causality exists flowing from the use of energy to $\mathrm{CO}_{2}$ emission and from $\mathrm{CO}_{2}$ emission to foreign direct investment for the 1980-2014 period via the pooled mean group model when they examined the influence that consumption of energy, economic growth and foreign direct investment have on the level of environmental pollution in case of 6 selected sub-Saharan African nations. In the case of the same Nigerian economy, Ifeyinwa and Chioma (2019) investigated the influence of variations in crude oil price on the selected macroeconomic series for the period covering 1981-2016 and with the aid of ARDL approach. The result indicates that variations in crude oil price possess some significant positive influence on government expenditure and revenue but there was no significant positive influence on the domestic price level.

Ahmad et al. (2018) in case of Chinese economy revealed that energy consumption and economic growth are the two variables accountable for the rising level of the country's $\mathrm{CO}_{2}$ 
emissions and that one-way causality exist running from economic growth to $\mathrm{CO}_{2}$ emissions for the period from 1971 to 2013 using autoregressive distributed lag model and Granger causality test respectively. Isik et al. (2018) demonstrated that a long run equilibrium connection exists among economic growth, $\mathrm{CO}_{2}$ emissions, energy consumption and urbanization alongside the influence of economic growth and energy consumption on $\mathrm{CO}_{2}$ emissions whereas the influence of urbanization on $\mathrm{CO}_{2}$ emissions is found in the national and medium developed provinces respectively when they used the technique of heterogeneous panel data analysis in their analysis of the energy consumption, economic growth, urbanization and environmental pollution interrelationship. In their investigation for possible existence of relationship between energy consumption, economic growth and $\mathrm{CO} 2$ emissions, Balcilar et al. (2018) opined that to reduce the level of $\mathrm{CO}_{2}$ emissions in the G-7 member countries, there is a need for the countries of Italy USA, Japan and Canada to forgone those economic activities via the provision of energy consumption from non-renewable source whereas in the countries that include Germany, US, Canada, Japan and UK there was absence of environmental kuznet curve since economic growth does not affect the quality of the environment in Germany and United Kingdom. In another development, Bala and Lee (2018) explored the asymmetric influence of crude oil price fluctuations on inflation in the case of four African oil producing nations for the period from 1975 to 2015 and panel ARDL approach for the short and the long run influences. The outcome of their exploration revealed that both positive and negative crude oil price changes have influenced on inflation and that the influence was stronger in the presence of decline in crude oil prices. Again, the rate of exchange, supply of money and economic growth were positively associated with inflation with food production related negatively to inflation. In the case of Algerian economy, Smahi and Mohamed (2018) explored the connection between crude oil price and the nominal exchange rate of local currency per US dollar for the 2008-2015 monthly periods and the exploration analysis was done with the aid of VECM approach. Their outcomes indicate that the series exhibit cointegration relation and that there exists two-way feedback among crude oil price and exchange rate with crude oil price haven a negative influence on Algerian currency exchange rate. Similarly using the same case of Algerian economy, Djebbouri (2018) investigated the effects of crude oil shocks on the Algerian currency exchange rate and investigation was possible through the utilization of VECM approach to data analysis in order to obtain the dynamic connection among these variables from 1980 to 2017 periods. His findings revealed that there is an existence of a negative influence that crude oil price changes exert on the Algerian currency exchange rate.

In the case of South African economy, Khobai and Le Roux (2017) in their examination for the connection between energy consumption, $\mathrm{CO}_{2}$ emissions, economic growth, trade openness and urbanization for the sample period from 1971 to 2013 utilized Johansen Juselius test for cointegration together with the Granger causality test based on VECM framework. They, found that apart from the cointegration connection among the series, there exist two-way causality running from energy consumption to economic growth. Using the sample of 17 group of South and Southeast Asian (SSEA) countries for the period from 1980 to 2012 and applying Pedroni cointegration approach, Behera and Dash (2017) studied the likely interrelationship between energy consumption, $\mathrm{CO}_{2}$ emissions, foreign direct investment, urbanization. The result revealed that after the existence of cointegration relationship among the series, energy consumption from fossil fuel significantly influenced $\mathrm{CO}_{2}$ emissions. But in the case of Ecuador economy applying the same ARDL procedure, Nwani (2017) investigated the correlation existing between the price of crude 
oil, $\mathrm{CO}_{2}$ emissions, economic growth and energy consumption for the 1971-2013 period. The outcome of the investigation revealed that greater amount of revenue from oil exports creates economic situations that necessitates added energy consumption which consequently led to $\mathrm{CO}_{2}$ emissions within the two periods. One-way causality exists from price of crude oil to consumption of energy and to economic growth; $\mathrm{CO}_{2}$ emissions to economic growth with two-way causality from consumption of energy to $\mathrm{CO}_{2}$ emissions. Using the same panel structural VAR approach to analysis covering the data from 1980-2015 periods, Rotimi and Ngalawa (2017) explored the influence of shocks in crude oil price on the performance of macroeconomic indicators in the case of African crude oil exporting nations. The results indicated that there is a significant feedback from the indicators due to shocks in crude oil price within the study period and it has a great influence on the performance of African crude oil exporting nations' economies with crude oil price transmission resulting in monetary medium. Furthermore, using structural VAR, EGARCH and granger causality in the case of Nigerian and Angolan economies and considering data on the interest series for the period under investigation, Ogunsakin and Oloruntuyi (2017) explored the connection between volatility in the price of crude oil and the performance of macroeconomic series. Their exploration outcomes indicated that volatility in the price of crude oil has a great influence on the economic growth of these nations while impulse response and variance decomposition results indicated that exchange rate response to shocks in crude oil price is the highest. In the case of Kuwait, Salahuddin et al. (2017) reported that economic growth, foreign direct investment and consumption of electricity were responsible for the increasing level of country's $\mathrm{CO}_{2}$ emissions with foreign direct investment and economic growth granger causing $\mathrm{CO}_{2}$ emissions in a VECM framework when they investigate the influence that economic growth and foreign direct investment have on the level of $\mathrm{CO}_{2}$ emissions for the period spanning from 1980 to 2013 and utilized ARDL approach.

Based on the available reviewed literature, to the best knowledge of the authors, there is no single study regarding the effects of crude oil price and urbanization on environmental pollution in the case of six selected African OPEC member countries of Algeria, Angola, Congo, Equatorial Guinea, Gabon and Nigeria and even if there is, they are single country base studies. Therefore, to fill this gap in the literature, this paper contributes to the prevailing literature through examining the influence of crude oil price and urbanization on environmental pollution in the case of Algeria, Angola, Congo, Equatorial Guinea, Gabon and Nigeria for the period from 1986 to 2018 and applies panel autoregressive distributed lag model.

\section{Method}

\section{Data and Econometric Modelling}

The main focus of this paper is to examine the influence of crude oil price and urbanization on environmental pollution in the case of selected OPEC African member countries for the sample duration from 1986 to 2018. The selected countries include Angola, Algeria, Congo, Equatorial Guinea, Gabon and Nigeria. The justification for this selection was based on the availability of data on all the series in the six selected countries. To drive the econometric model for this study, we have followed the empirical models of Maijama'a and Musa (2020) and Mahmood (2020) who studied the impact of crude oil price and urbanization on environmental pollution in two different countries, Nigeria and Saudi Arabia. Their model is given as:

$$
E V_{t}=f\left(O P_{t}, U B_{t}, F I_{t}\right)
$$


Following the above model presented in Equation 1, our modified model with the inclusion of economic growth for this study is given in Equation 2:

$$
E P_{i t}=f\left(O P_{i t}, U B_{i t}, F I_{i t}, E C_{i t}\right)
$$

Equation 2 is the functional form of the relationship between crude oil price, urbanization and environmental pollution. To make it easier for the interpretation of the coefficients more meaningful and most importantly to reduce the problem of heteroskedascity, we have converted the series into natural logarithm (Ahmed et al., 2015; Fauzel, 2019; Maji, 2015; Musa et al., 2019; Sulaiman \& Abdur-Rahim, 2018). The Equation 3 shows the outcome of the conversion.

$$
\ln E P_{i t}=\theta_{0}+\theta_{1} \ln O P_{i t}+\theta_{2} \ln U B_{i t}+\theta_{3} \ln F I_{i t}+\theta_{4} \ln E C_{i t}+\mu_{i t}
$$

Where the natural logarithm sign is given by $\ln$; drift parameter is given by $\theta_{0}$; EP is the abbreviation for the environmental pollution; the abbreviation for the crude oil price is OP; UB stands for the urbanization; FI is the foreign direct investment; EC represents economic growth; $\theta_{1} \ldots \theta_{4}$ are the explanatory variables coefficients; i represents the six selected African OPEC member countries; $t$ is the time periods (1986-2018); white noise is given by $\mu$. The data for this research was obtained from two different sources and the description of the variables are presented in Table 1.

Table 1

\begin{tabular}{|c|c|c|c|}
\hline Series & Definition & Justification & Sources \\
\hline $\mathrm{EP}_{\mathrm{it}}$ & $\mathrm{CO}_{2}$ emission per capita & $\begin{array}{l}\text { Fauzel, 2019; Musa et al., (2020); Han \& Lee (2013); } \\
\text { Tiwari (2011); Mahmood, (2020). }\end{array}$ & WDI, 2020 \\
\hline $\mathrm{OP}_{\text {it }}$ & Crude oil price (US\$ per barrel) & Mahmood, (2020); Musa et al. (2020). & EIA, 2020 \\
\hline $\mathrm{UB}_{\text {it }}$ & Urban population & Mahmood, (2020); Musa et al. (2020). & WDI, 2020 \\
\hline $\mathrm{FI}_{\mathrm{it}}$ & $\begin{array}{l}\text { Foreign direct investment, net inflows (\% of } \\
\text { GDP) }\end{array}$ & Fauzel, (2019) & WDI, 2020 \\
\hline $\mathrm{EC}_{\text {it }}$ & GDP per capita (Constant 2010 US\$) & Fauzel, (2019); Han \& Lee (2013); Tiwari (2011). & WDI, 2020 \\
\hline
\end{tabular}

Variables Definition, Justifications and Sources

As discussed above, the Panel autoregressive distributed lag (PARDL) method to cointegration has been utilized. The PARDL model is engaged due to its numerous characteristics ranging from offering efficient estimated long run coefficients, unbiased coefficients and effective t-statistics even when some of the regressors are offered as endogenous series (Harris \& Sollis, 2003; Pesaran, Shin, \& Smith, 2001). Therefore, the goal of this research is to inspect the connection between environmental pollution, crude oil price and urbanization in the short run as well as the long run periods and the Mean Group (MG) together with the Pooled Mean Group (PMG) estimators utilized in the inspection determinations. Lastly, to decide regarding the utilization of either MG or PMG estimators, we have engaged the Hausman Test.

\section{Mean Group Estimator}

The discussion about the concept of MG estimator was first given by Pesaran et al. (1999) and they reasoned on the separate estimation of regressors regarding individual nations in the sample as well as estimating the coefficients as unweight means of the calculated coefficients for the individual nation. And by doing that, there will be absence of imposition regarding any kind of limitations. Therefore, this permits all the coefficients to fluctuate and remain heterogeneous in both the short run and the long run period. Regarding the individual nations, the long-run coefficients are offered by the context of mean group for these individual nations. Thus, the ARDL is presented in Equation 4:

$$
Y_{i t}=\beta_{0}+\beta_{1} Y_{i, t-1}+\varepsilon_{i t}
$$


In Equation 4, for the country $\mathrm{i}$, here $\mathrm{I}=1,2,3 \ldots \mathrm{n}$ and $\delta_{\mathrm{i}}$ is given as the long run parameter for the country $i$ and is offered in Equation 5:

$$
\delta_{i}=\frac{\chi_{i}}{1-\beta_{i}}
$$

But however, the entire mean group estimator for the panel is presnted in Equation 6 and 7 respectively.

$$
\widehat{\delta}_{i}=\frac{1}{n} \sum_{i=1}^{n} \delta_{i}
$$

$$
\widehat{\beta}_{i}=\frac{1}{n} \sum_{i=1}^{n} \beta_{i}
$$

\section{Pooled Mean Group Estimator}

After the MG (mean group) model, we also have the PMG (pooled mean group) model. At this point, the coefficients of the short run drifts parameters the adjustment speed toward the long run equilibrium in addition to the error variances are permitted to be varied by nations. Nevertheless, the long run slope coefficients were restricted to be consistent across the nations. The unlimited description regarding the ARDL system of Equations for different successive periods of time and for the sum of the countries for the explain series $\mathrm{Y}$ is given in Equation 8:

$$
Y_{i t}=\sum_{p=1}^{k} \varphi_{i p} \ln Y_{i, t-p}+\sum_{p=1}^{m} \alpha_{i p} \ln X_{1 i, t-p}+\mu_{i}+\varepsilon_{i t}
$$

Here $X_{i, t-p}$ is the $(K \times 4)$ vector of explanatory series for the group i whereas the fixed effect is represented by the $\mu_{\mathrm{i}}$ sign in the Equation 8 and $\varepsilon_{\mathrm{it}}$ represents the disturbance term. To write the Vector Error Correction form of the above Equation, we have developed Equation 9 and it is correctly estimated:

$$
\Delta Y_{i t}=\vartheta_{i}\left(Y_{i, t-1}+\phi^{\prime} X_{i, t-1}\right)+\sum_{p=1}^{k-1} \varphi_{i p} \Delta Y_{i, t-p}+\sum_{p=1}^{m-1} \alpha_{i p}^{\prime} \Delta X_{i, t-p}+\mu_{i}+\varepsilon_{i t}
$$

In Equation above, the coefficients of long run parameters are given by $\phi_{i}$ and the parameters of error correction are represented by $\vartheta_{i}$ respectively. The elements of $\phi$ are mutual across the nations according to the Pooled mean group (PMG) estimator:

$$
\Delta Y_{i t}=\vartheta_{i}\left(Y_{i, t-1}+\phi^{\prime} X_{i, t-1}\right)+\sum_{p=1}^{k-1} \varphi_{i p} \Delta Y_{i, t-p}+\sum_{p=1}^{m-1} \alpha_{i p}^{\prime} \Delta X_{i, t-p}+\mu_{i}+\varepsilon_{i t}
$$

And that the entire dynamics and the error correction model terms are free to change in Pooled Mean Group (PMG) model.

\section{Error Correction Term}

The representation of the error correction term that aid in the reestablishment of the equilibrium in the dynamic model is done by the convergence speed. Because the term offered suggestion on how quickly the series attained the equilibrium position. However, there are three criterions that the error correction term must be fulfilled that is the coefficient must be less than one, negative and statistically significant (Banerjee, Dolado, \& Mestre, 1998).

\section{The Hausman Test}

To determine which one among the Mean Group (MG) coefficients or Pooled Mean Group (PMG) coefficients is more efficient, we have utilized the Hausman test and in the case of homogenous parameters, it is a strong indication that PMG estimates are the most appropriate instead of the MG 
estimates. Therefore, the efficient estimates are the PMG under the null hypothesis and MG estimates are more appropriate under the alternative hypothesis. In the current inspection, the outcome of the Hausman test revealed that the p-value is higher than.05 and this is an indication that PMG is more appropriate and hence only the PMG outcomes are discussed below.

\section{Results}

This section is devoted to the graphical illustration of all the variables utilized in our study including economic growth, environmental pollution, urban population and foreign direct investment respectively. It can be observed from Figure 1 that Nigeria has the last average economic growth and Gabon has the highest. On the basis of environmental pollution, Gabon also has the highest level and Nigeria has the least on average basis. In terms of urban population, Nigeria has the highest and Equatorial Guinea has the least on average basis. Again, Nigeria has the highest average inflow of foreign direct investment and Algeria has the least respectively.
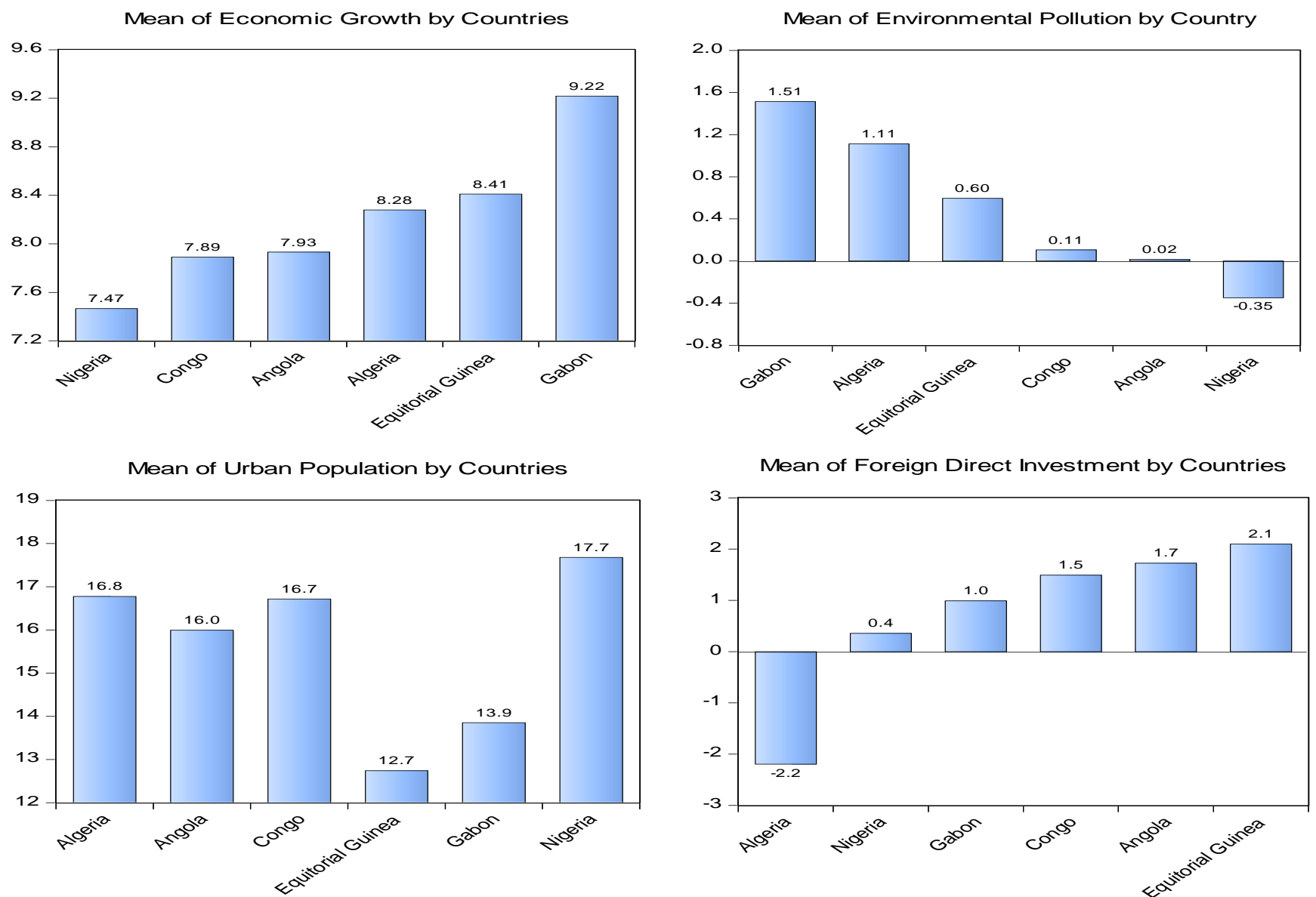

Figure 1. Graphical illustration of the variables (Source: Authors' Presentation using Data from WDI, 2020).

The description of the series and areas of description including the average values, the highest and the lowest values, the standard deviation, the skewness, the normality test using Jarque Bera and its $\mathrm{p}$-values and the lastly the total observations are presented in Table 2. The Jarque Bera p-values for $\mathrm{EP}_{\mathrm{it}}, \mathrm{OP}_{\mathrm{it}}$ and $\mathrm{UB}_{\mathrm{it}}, \mathrm{FI}_{\mathrm{it}}$ were highly significant at .01 and this is an indication of not normally distributed series within the study period in the model. Whereas the $\mathrm{p}$-value of $\mathrm{EC}_{\mathrm{it}}$ appeared to be insignificant and this implies that it is normally distributed in the model within the sample period. Table 2 
Descriptive Statistics

\begin{tabular}{|c|c|c|c|c|c|c|c|}
\hline Series & Mean & Max. & Min. & SD & Skew. & JB [p-values] & Obs. \\
\hline$\overline{E P_{i t}}$ & 0.47 & 1.88 & -1.96 & 0.85 & -0.45 & $6.78^{* * * *}[0.033]$ & 170 \\
\hline $\mathrm{OP}_{\mathrm{it}}$ & 3.56 & 4.60 & 2.66 & 0.64 & 0.27 & $16.42^{* * *}[0.000]$ & 170 \\
\hline $\mathrm{UB}_{\text {it }}$ & 15.63 & 18.40 & 11.64 & 1.87 & -0.57 & $15.66^{* * *}[0.000]$ & 170 \\
\hline $\mathrm{FI}_{\mathrm{it}}$ & 0.64 & 5.08 & -13.12 & 2.55 & -2.98 & $1471.81^{* * * *}[0.000]$ & 170 \\
\hline $\mathrm{EC}_{\text {it }}$ & 8.15 & 9.89 & 6.20 & 0.83 & 0.09 & $0.78[0.676]$ & 170 \\
\hline
\end{tabular}

Given that four consecutive series were not normally distributed as indicated by their Jarque bera probability values in Table 2, Table 3 presents some insight regarding the correlation relationship between our variables and most importantly the multicollinearity problem. It can be observed that there is a positive correlation between crude oil price and environmental pollution and between economic growth and environmental pollution while negative correlation flows from urbanization and environmental pollution and foreign direct investment and environmental pollution. Most importantly, the correlation values among our series were within the .80-1.00 bench mark and this is a strong indication for the absence of multicollinearity problem in our variables (Pordan, 2013). Table 3

\begin{tabular}{lccccc} 
Correlation Analysis & \multicolumn{5}{l}{} \\
\hline Series & $\mathrm{EP}_{\mathrm{it}}$ & $\mathrm{OP}_{\mathrm{it}}$ & $\mathrm{UB}_{\mathrm{it}}$ & $\mathrm{FI}_{\mathrm{it}}$ & \\
\hline $\mathrm{EP}_{\mathrm{it}}$ & 1.00 & & & & \\
$\mathrm{OP}_{\mathrm{it}}$ & 0.17 & 1.00 & & & \\
$\mathrm{UB}_{\mathrm{it}}$ & -0.29 & 0.18 & 1.00 & 1.00 & \\
$\mathrm{FI}_{\mathrm{it}}$ & -0.09 & 0.19 & -0.26 & 0.006 & 1.00 \\
$\mathrm{EC}_{\mathrm{it}}$ & 0.84 & 0.41 & -0.30 & & \\
\hline
\end{tabular}

In this section of the data analysis, the unit root test using panel Fisher type unit root tests of ADF-Fisher and PP-Fisher as suggested by Choi (2001) were utilized and their outcomes are reported in Table 4. The unit root test result from Fisher-ADF indicated that urbanization and foreign direct investment were stationary at level forms and these series are said to be integrated with order zero and they are indicated by $\mathrm{I}(0)$. But environmental pollution, crude oil price and economic growth were not stationary at level forms both using constant and constant and trend but became stationarity level only after first differencing and these variables are said to be integrated with order one and are indicated by I(1). Therefore, using Fisher-ADF panel unit root test there is mixture of order of integration with the series, and Fisher-ADF panel unit root test results supported the application of panel ARDL approach.

Fisher-PP panel unit root test outcome is also reported at the second part of Table 4. The outcome indicated that urbanization and foreign direct investment were stationary at level forms and these series are said to be integrated with order zero and they are indicated by $\mathrm{I}(0)$. But environmental pollution, crude oil price and economic growth were not stationary at level forms both using constant and constant and trend but became stationarity level only after first differencing and, these variables are said to be integrated with order one and are indicated by I(1). Also, Fisher-PP panel unit root test outcome indicated a mixture of order of integration with the series and, Fisher-PP panel unit root test result also supported the application of panel ARDL approach.

In summary, both the Fisher-ADF and Fisher-PP panel unit roots tests outcomes indicated that panel ARDL approach is more efficient in determining the long run and short run relationship between crude oil price, urbanization and environmental pollution in the case of selected African OPEC member countries of Algeria, Angola, Congo, Equatorial Guinea, Gabon and Nigeria for 1986-2018 period. 
Table 4

Fisher-ADF and PP Unit Root Test Results

\begin{tabular}{|c|c|c|c|c|c|}
\hline \multirow[b]{3}{*}{ Series } & \multicolumn{2}{|c|}{ Level } & \multicolumn{2}{|c|}{ First Difference } & \multirow[t]{2}{*}{ Interpretation } \\
\hline & $\mathrm{C}$ & $\mathrm{C} \& \mathrm{~T}$ & $\mathrm{C}$ & $\mathrm{C} \& \mathrm{~T}$ & \\
\hline & \multicolumn{4}{|c|}{ Fisher-ADF Unit Root Test Outcome } & \\
\hline \multirow{2}{*}{$\mathrm{EP}_{\mathrm{it}}$} & 13.28 & 11.32 & $62.86^{* * *}$ & $56.98^{* * * *}$ & I (1) \\
\hline & $(0.20)$ & $(0.33)$ & $(0.000)$ & $(0.000)$ & \\
\hline \multirow[t]{2}{*}{$\mathrm{OP}_{\mathrm{it}}$} & 3.36 & 6.45 & $68.72^{* * *}$ & $51.82^{* * *}$ & $\mathrm{I}(1)$ \\
\hline & $(0.97)$ & $(0.77)$ & $(0.000)$ & $(0.000)$ & \\
\hline \multirow[t]{2}{*}{$\mathrm{UB}_{\text {it }}$} & 5.65 & $67.74^{* * *}$ & $42.19^{* * *}$ & $34.18^{* * *}$ & $\mathrm{I}(1)$ \\
\hline & $(0.93)$ & $(0.000)$ & $(0.000)$ & $(0.000)$ & \\
\hline \multirow[t]{2}{*}{$\mathrm{FI}_{\mathrm{it}}$} & $19.18^{* *}$ & $19.55^{* *}$ & $55.18^{* * *}$ & $42.40^{* * *}$ & $\mathrm{I}(0)$ \\
\hline & $(0.03)$ & $(0.03)$ & $(0.000)$ & $(0.000)$ & \\
\hline \multirow[t]{2}{*}{$\mathrm{EC}_{\mathrm{it}}$} & 4.98 & 9.29 & $35.78^{* * *}$ & $24.25^{* * *}$ & $\mathrm{I}(1)$ \\
\hline & $(0.89)$ & $(0.50)$ & $(0.000)$ & $(0.007)$ & \\
\hline \multicolumn{6}{|c|}{ Fisher-PP Unit Root Test Outcome } \\
\hline \multirow[t]{2}{*}{$\mathrm{EP}_{\mathrm{it}}$} & 12.63 & 11.07 & $100.36^{* * *}$ & $89.43^{* * *}$ & $\mathrm{I}(1)$ \\
\hline & $(0.24)$ & $(0.35)$ & $(0.000)$ & $(0.000)$ & \\
\hline \multirow[t]{2}{*}{$\mathrm{OP}_{\mathrm{it}}$} & 4.25 & 5.34 & $92.10^{* * *}$ & $69.17^{* * *}$ & $\mathrm{I}(1)$ \\
\hline & $(0.93)$ & $(0.86)$ & $(0.000)$ & $(0.000)$ & \\
\hline \multirow[t]{2}{*}{$\mathrm{UB}_{\mathrm{it}}$} & $40.90^{* * * *}$ & $28.02^{* * *}$ & $19.79^{*}$ & 5.89 & $\mathrm{I}(0)$ \\
\hline & $(0.000)$ & $(0.000)$ & $(0.07)$ & $(0.92)$ & \\
\hline \multirow[t]{2}{*}{$\mathrm{FI}_{\mathrm{it}}$} & $60.81^{* * *}$ & $57.41^{* * *}$ & $383.06^{* * *}$ & $159.87^{* * *}$ & $\mathrm{I}(0)$ \\
\hline & $(0.000)$ & $(0.000)$ & $(0.000)$ & $(0.000)$ & \\
\hline \multirow[t]{2}{*}{$\mathrm{EC}_{\mathrm{it}}$} & 5.60 & 7.24 & $65.37^{* * *}$ & $54.07^{* * * *}$ & $\mathrm{I}(1)$ \\
\hline & $(0.84)$ & $(0.70)$ & $(0.000)$ & $(0.000)$ & \\
\hline
\end{tabular}

After identifying the order of integration that guarantee the application of panel ARDL model, the outcome of the panel ARDL approach is reported in Table 5. The outcome of the pooled mean group in the long run indicated that crude oil price exerts negative and significance effects on environmental pollution. Specifically, one percent increase in crude oil price in the global market is associated with.09 percent decrease in the level of environmental pollution in the exploration countries of Algeria, Angola, Congo, Equatorial Guinea, Gabon and Nigeria within the sample period under study. This implies that revenue generated from crude oil exports are engaged in financing clean technologies in these countries. But in the short run period, crude oil price had a positive relationship with environmental pollution and more specifically, one dollar increase in the price of crude oil per barrel in the global energy market was associated with.04 percent increase in unemployment in these six selected economies.

Similarly, urbanization has signed negatively with environmental pollution in the long run and precisely, one percent increase in urban population will bring out .38 percent decrease in the level of environmental pollution in the case of Algeria, Angola, Congo, Equatorial Guinea, Gabon and Nigeria. This implies that environmental protection policies in these countries are not defunct and are closely monitored by the responsible agencies. Also, in the short run period, urbanization had a negative impact on environmental pollution and more precisely, one percent increase in urban population is connected with 4.61 percent decrease in environmental population and this implies that the magnitude of short run effect is more than that of the long run effect.

Again, foreign direct investment had a negative correlation with the environmental pollution in the economies of Algeria, Angola, Congo, Equatorial Guinea, Gabon and Nigeria. One percent increase in the inflow of foreign capital into any of these six selected economies was associated with.08 percent decrease in environmental pollution in the long run period. This is an indication that foreign investors in these countries also play some role in reducing environmental pollution through the utilization of environmentally friendly technologies. Similarly, foreign direct investment exerted a 
significant negative impact on environmental pollution in the short run period. More concise, one percent increase in the inflow of foreign investment into these economies was associated with.01 percent decrease in environmental pollution. In this case, the magnitude of inflow of foreign direct investment in the long run is greater than that of the short run period.

Economic growth of these nations appears to be positive and significant with environmental pollution as one percent increase in economic growth is associated with.20 and.44 percent increase in environmental pollution in the long run and the short period as indicated by the pooled mean group outcome. This finding implies that these economies engage in activities that are not environmentally friendly and affect the nature of the environment in the process of achieving higher economic growth.

The coefficient of error correction term has satisfied the three econometric conditions of being negative, less than one and statistically significant. Therefore, these three conditions have confirmed the cointegration relationship and speed of adjustment among our series. Particularly, the error correction value of -0.26 approximately implies that the speed of convergence from short run disequilibrium back to equilibrium is at a slow rate of 26 percent every year.

Table 5

Pooled Mean Group Outcome (Dependent Variable $\operatorname{lnEP} P_{i t}$ )

\begin{tabular}{|c|c|c|c|c|}
\hline Variables & Coefficient & Std. Error & t-Statistic & P-values \\
\hline \multicolumn{5}{|c|}{ Long Run Estimation } \\
\hline $\operatorname{lnOP}_{\text {it }}$ & $-0.09^{* *}$ & 0.04 & -2.25 & .02 \\
\hline $\operatorname{lnUB}{ }_{\text {it }}$ & $-0.38^{* * *}$ & 0.08 & -4.55 & .001 \\
\hline $\operatorname{lnFI} \mathrm{I}_{\mathrm{it}}$ & $-0.08^{* * *}$ & 0.02 & -3.89 & .001 \\
\hline $\operatorname{lnEC_{it}}$ & $0.20^{*}$ & 0.10 & 1.95 & .05 \\
\hline \multicolumn{5}{|c|}{ Short Run Estimation } \\
\hline ECT (-1) & $-0.25^{* *}$ & 0.09 & -2.56 & .01 \\
\hline$\Delta \operatorname{lnOP}{ }_{\text {it }}$ & $0.04^{*}$ & 0.02 & 1.85 & .06 \\
\hline$\Delta \ln U B_{i t}$ & $-4.61^{* *}$ & 1.82 & -2.53 & .01 \\
\hline$\Delta \operatorname{lnFI} \mathrm{it}_{\mathrm{it}}$ & $0.01^{* * *}$ & 0.006 & 2.98 & .003 \\
\hline$\Delta \operatorname{lnE} C_{\text {it }}$ & $0.44^{* * *}$ & 0.14 & 2.96 & .003 \\
\hline Constant & $1.55^{* * *}$ & 0.54 & 2.87 & .004 \\
\hline
\end{tabular}

Note. $* p<.05, * * p<.01, * * * p<.001$.

Considering our long run coefficients estimated from the pooled mean group estimation, we have utilized the panel dynamic ordinary least squares developed by Stock and Warson (1993) and fully modified ordinary least squares developed by Philip and Moon (1999) to examine simultaneity bias, problem of small sample size, serial correlation problem and endogeneity problem and their outcomes are reported in Table 6. From the dynamic and fully modified ordinary least squares model results crude oil price, urbanization and foreign direct investment have negatively signed with environmental pollution while economic growth exerted a positive impact on environmental pollution. In summary, all the outcomes under these two estimators have confirmed the long run pooled mean group outcomes respectively.

Table 6

Dynamic and Fully Modified Ordinary Least Squares Results

\begin{tabular}{|c|c|c|c|c|c|c|}
\hline \multirow[b]{2}{*}{ Variables } & \multicolumn{3}{|c|}{ DOLS } & \multicolumn{3}{|c|}{ FMOLS } \\
\hline & Coefficient & $t$ & $p$ & Coefficient & $t$ & $p$ \\
\hline $\operatorname{lnOP} \mathrm{P}_{\mathrm{it}}$ & $\begin{array}{c}-0.31^{* *} \\
{[0.15]}\end{array}$ & -2.11 & .03 & $\begin{array}{c}-.17^{* * *} \\
{[.04]}\end{array}$ & -3.63 & .001 \\
\hline $\ln \mathrm{UB}_{\text {it }}$ & $\begin{array}{l}-0.62^{* *} \\
{[0.28]}\end{array}$ & -2.17 & .03 & $\begin{array}{c}-.067^{* * *} \\
{[.001]}\end{array}$ & -45.74 & .001 \\
\hline $\operatorname{lnFI} I_{i t}$ & $\begin{array}{l}-0.009 \\
{[0.02]}\end{array}$ & -0.32 & .74 & $\begin{array}{l}-.065 \\
{[.09]}\end{array}$ & -0.71 & .47 \\
\hline $\operatorname{lnEC_{it}}$ & $\begin{array}{c}1.25^{* * *} \\
{[0.14]}\end{array}$ & 8.85 & .001 & $\begin{array}{l}.86^{* * *} \\
{[.002]}\end{array}$ & 409.50 & .001 \\
\hline
\end{tabular}


The direction of causality among our variables was determined through the means of Dumitrescu and Hurlin (2012) Pairwise panel granger causality test and the outcome of the test is reported in Table 7. The outcome indicated that there is an existence of feedback hypothesis between urbanization and environmental pollution, economic growth and environmental pollution, economic growth and crude oil price and economic growth with urbanization respectively. Unidirectional causality also existed flowing from crude oil price to environmental pollution and foreign direct investment to economic growth. Also, there existed the independent causality flowing from foreign direct investment to environmental pollution, foreign direct investment to crude oil price and foreign direct investment to urbanization respectively.

Table 7

Pairwise Dumitrescu Hurlin Panel Causality Tests

\begin{tabular}{|c|c|c|c|c|}
\hline Null Hypothesis & W-Stat. & Zbar-Stat. & $p$ & Causality Direction \\
\hline $\operatorname{lnOP}_{\text {it }}$ does not homogeneously cause $\operatorname{lnEP} \mathrm{it}_{\mathrm{it}}$ & $7.60^{* * * *}$ & 5.65 & .001 & Unidirectional Causality \\
\hline $\operatorname{lnEP}_{\text {it }}$ does not homogeneously cause $\operatorname{lnOP}$ it & 1.03 & -1.17 & .23 & \\
\hline $\operatorname{lnUB}_{\text {it }}$ does not homogeneously cause $\operatorname{lnEP_{\text {it}}}$ & $11.81^{* * *}$ & 10.02 & .001 & Bidirectional Causality \\
\hline $\operatorname{lnEP}_{\text {it }}$ does not homogeneously cause $\ln \mathrm{UB}_{\text {it }}$ & $10.53^{* * *}$ & 8.70 & .001 & \\
\hline $\operatorname{lnFI}_{i t}$ does not homogeneously cause $\operatorname{lnEP_{it}}$ & 1.58 & -0.62 & .53 & Independent Causality \\
\hline $\operatorname{lnEP}_{\text {it }}$ does not homogeneously cause $\operatorname{lnFI} \mathrm{it}_{\mathrm{it}}$ & 1.66 & -0.54 & .58 & \\
\hline $\operatorname{lnEC}_{\text {it }}$ does not homogeneously cause $\operatorname{lnEP_{it}}$ & $4.94^{* * *}$ & 2.89 & .003 & Bidirectional Causality \\
\hline $\operatorname{lnEP_{it}}$ does not homogeneously cause $\operatorname{lnEC_{it}}$ & $5.75^{* * *}$ & 3.73 & .001 & \\
\hline $\operatorname{lnUB}_{\text {it }}$ does not homogeneously cause $\operatorname{lnOP}_{\text {it }}$ & $3.97^{*}$ & 1.88 & .05 & Bidirectional Causality \\
\hline $\operatorname{lnOP}_{\text {it }}$ does not homogeneously cause $\ln U B_{i t}$ & $11.01^{* * *}$ & 9.20 & .001 & \\
\hline $\operatorname{lnOP}_{\mathrm{it}}$ does not homogeneously cause $\operatorname{lnFI} \mathrm{it}_{\mathrm{it}}$ & 2.81 & 0.58 & .55 & Independent Causality \\
\hline $\operatorname{lnFI}_{\text {it }}$ does not homogeneously cause $\operatorname{lnOP}_{\text {it }}$ & 1.42 & -0.78 & .43 & \\
\hline $\operatorname{lnEC}_{\text {it }}$ does not homogeneously cause $\operatorname{lnOP}_{\text {it }}$ & $6.17^{* * *}$ & 4.16 & .001 & Bidirectional Causality \\
\hline $\operatorname{lnOP}_{\text {it }}$ does not homogeneously cause $\operatorname{lnEC_{it}}$ & $5.68^{* * *}$ & 3.65 & .001 & \\
\hline $\operatorname{lnUB}_{\text {it }}$ does not homogeneously cause $\operatorname{lnFI}{ }_{i t}$ & 3.69 & 1.45 & .14 & Independent Causality \\
\hline $\operatorname{lnFI}_{\text {it }}$ does not homogeneously cause $\ln U B_{\text {it }}$ & 2.87 & 0.64 & .51 & \\
\hline $\operatorname{lnEC}_{i t}$ does not homogeneously cause $\ln \mathrm{UB}_{\mathrm{it}}$ & $15.80^{* * *}$ & 14.17 & .001 & Bidirectional Causality \\
\hline $\operatorname{lnUB}_{\text {it }}$ does not homogeneously cause $\operatorname{lnEC_{it}}$ & $12.78^{* * *}$ & 11.04 & .001 & \\
\hline $\operatorname{lnEC}_{\mathrm{it}}$ does not homogeneously cause $\operatorname{lnFI} \mathrm{it}_{\mathrm{it}}$ & 2.33 & 0.11 & .90 & Unidirectional Causality \\
\hline $\operatorname{lnFI}_{\text {it }}$ does not homogeneously cause $\operatorname{lnEC}_{\text {it }}$ & $4.83^{* * *}$ & 2.58 & .009 & \\
\hline
\end{tabular}

Note. $* p<.05, * * p<.01, * * * p<.001$.

\section{Conclusion and Recommendations}

Nigeria has been through speedy urbanization in the past few years which is largely due to the revenue generated from the exports of oil crude oil and this revenue has constituted an important part of the countries means of revenue generation since from the year 1980.

The current study examined the effect of urbanization and crude oil price on environmental pollution in the case of six selected African OPEC member countries and the objective of this analysis was realized with aid of panel ARDL approach for the 1986-2018 periods. Our finding from the pooled mean group model indicates that crude oil price, urbanization and foreign direct investment have a significant negative influence on environmental pollution in the long run period while in the short run, only urbanization has a significant negative impact on environmental pollution but all the remaining three variables have a significant positive impact on environmental pollution. There was slow speed of adjustment from short run disequilibrium back to equilibrium 
position estimated at 26 percent approximately every year. As a robustness checks to our pooled mean group long run coefficients, we have utilized the panel dynamic ordinary least square and fully modified ordinary least square because they are the perfect checks for the long run panel ARDL coefficients and their outcomes revealed the confirmation for the long run pooled mean group estimates.

The direction of causality among our variable was determined via the use of Pairwise Dumitrescu Hurlin panel causality test and the outcome of the test revealed that there is an existence of bilateral causality flowing from between urbanization to environmental pollution, economic growth to environmental pollution, economic growth to crude oil price and economic growth to urbanization respectively. While unidirectional causality also exists flowing from crude oil price to environmental pollution and foreign direct investment to economic growth, there also exist independent causality flowing from foreign direct investment to environmental pollution, foreign direct investment to crude oil price and foreign direct investment to urbanization respectively.

Therefore, on the basis of these empirical outcomes, it is recommended that for these six selected countries to achieve and maintain quality environment, these nations must restrict the speed of urbanization process to its optimum level and this process will decrease the environmental effects associated with it. But this does not imply the total closing of all activities and projects that focus on urbanization but just to ensure equilibrium in the process where the environmental quality is not affected by the growing number of urban populations since the effect of urban populations is negative in these countries as shown by the pooled mean group estimator.

With the existence of exertions regarding development and urbanization in some nations among the six selected countries, now it is the right time for the governments of these countries to produce and stretched plan that will continue to concentrate on exploration of crude oil, since the increasing crude oil price from the global energy market exerts positive effects on the entire revenue generated by these economies. Despite the fact that this revenue generated from crude oil exports and number of urban populations may have some associated welfare possessions via higher living standard, level of consumption increment and positive wellbeing realization by ignoring their joint negative impacts can lead to environmental pollution.

\section{References}

Ahmad, M., Hengyi, H., Rahman, Z. U., Khan, Z. U., Khan, S., \& Khan, Z., (2018). Carbon emissions, energy use, gross domestic product and total population in China. Ekonomia i Środowisko, 2(65), 32-44.

Ahmed, K., Shahbaz, M., Qasim, A., \& Long, W. (2015). The linkages between deforestation, energy and growth for environmental degradation in Pakistan. Ecological Indicators, 49, 95-103. https://doi.org/10.1016/j.ecolind.2014.09.040

Bala, U., \& Lee, C. (2018). Asymmetric impacts of oil Price on inflation: An empirical study of African OPEC member countries. Energies, 11, 1-21. https://doi.org/10.3390/en11113017

Balcilar, M., Ozdemir, Z. A., Ozdemir, H., \& Shahbaz, M. (2018). Carbon dioxide emissions, energy consumption and economic growth: The historical decomposition evidence from G-7 countries. Retrieved from https://ideas.repec.org/p/emu/wpaper/1541.pdf.html

Banerjee, A., Dolado, J., \& Mestre, R. (1998). Error-correction mechanism tests for cointegration in a single-equation framework. Journal of Time Series Analysis, 19(3), 267. https://doi.org/10.1111/1467-9892.00091.

Behera, S. M., \& Dash, D. P. (2017). The effect of urbanization, energy consumption, and foreign direct investment on the carbon dioxide emission in the SSEA (South and Southeast Asian) region. Renewable and Sustainable Energy Reviews, 70(C), 96-106.https://doi.org/10.1016/j.rser.2016.11.201. 
Choi, I. (2001). Unit root tests for panel data. Journal of International Money and Finance, $20(2)$, $249-272$. http://dx.doi.org/10.1016/S0261-5606(00)00048-6

Claessens, S., \& Feijen, N. (2007). Financial sector development and the millennium development goals. World Bank Working Paper, No. 89.

Dumitrescu, E.I. \& Hurlin, C. (2012). Testing for granger causality non-causality in Heterogeneouspanels. Economic Modelling, 29, 145-1460.https://doi.org/10.1016/j.econmod.2012.02.014

Djebbouri, M. (2018). Impact of oil price shocks on exchange rate in Algeria. International Journal of Finance and Accounting, 7(5), 133-141.

EIA, (2020). Cushing, OK WTI Spot Price FOB (Dollars per Barrel) Retrieved from https://www.eia.gov/dnav/pet/hist/leafHandler.ashx?n=PET\&s=RWTC\&f=A

Fauzel, S. (2019). Energy consumption and economic growth for small island developing states: A panel ARDL approach. Energy Economics Letters, 6(1), 23-29.https://doi.org/10.18488/journal.82.2019.61.23.29

Han, C., \& H. Lee (2013). Dependence of economic growth on $\mathrm{CO}_{2}$ emissions. Journal of Economic Development, $38(1)$, $47-57$. https://doi.org/10.35866/caujed.2013.38.1.003

Harris, R., \& Sollis, R. (2003). Applied time series modelling and forecasting. Chichester: Wiley.

Ifeyinwa, H. F., \& Chioma, O. D. (2019). Impact of oil price changes on selected macroeconomic variables in Nigeria. South Asian Journal of Social Studies and Economics, 4(1), 1-10. https://doi.org/10.9734/SAJSSE/2019/v4i130116.

Isik, C., Dogru, T., \& Turk, E. S. (2018). A nexus of linear and non-linear relationships between tourism demand, renewable energy consumption, and economic growth: Theory and evidence. International Journal of Tourism Research, 20(1), 38-49. https://doi.org/10.3390/su10072383

Khobai, H., \& Le Roux, P. (2017). The relationship between energy consumption, economic growth and carbon dioxide emission: The case of South Africa. International Journal of Energy Economics and Policy, 7(3), $102-109$. https://doi.org/10.1504/ijse.2018.10009728.

Mahmood, H. (2020). Impact of financial market development on the $\mathrm{CO}_{2}$ Emissions in GCC countries. Accounting, 6, 649-656.

Mahmood, H., Alkhateeb, T. T. Y., Al-Qahtani, M. M. Z., Allam, Z., Ahmad, N., \& Furqan, M., (2020). Urbanization, oil price and pollution in Saudi Arabia. International Journal of Energy Economics and Policy, 10(2), 477-482. http://dx.doi.org/10.32479/ijeep.8914

Mahmooda, H., Alkhateeba, T. T. Y., Al-Qahtani, M. M. Z., Allam, Z., Ahmad, N., \& Furqan, M. (2019). Energy consumption, economic growth and pollution in Saudi Arabia. Management Science Letters, 10(5), 979-984.

Maijama'a, R., \& Musa, K. S. (2020). Crude oil price fluctuation and unemployment nexus in Nigeria: Evidence from VECM technique. Energy Economic Letters, 7(2), 94-109.

Maijama'a, R., \& Musa, K. S. (2020). crude oil price, urbanization and environmental pollution in Nigeria: Evidence from ARDL approach. Asian Journal of Economic Modelling, 8(4), 227-240. https://doi.org/10.18488/journal.8.2020.84.227.240

Maji, I. K. (2015). The link between trade openness and deforestation for environmental quality in Nigeria. Geo Journal, 82(1), 131-138.https://doi.org/10.1007/s10708-015-9678-7.

Musa, K. S., Maijama'a, R., Shaibu, H. U., \& Muhammad, A. (2019). Crude oil price and exchange rate on economic growth: ARDL approach. Open Access Library Journal, 6(5), 1-16.

Musa, K. S., \& Maijama'a, R. (2020). Economic growth, energy consumption and environmental pollution in Nigeria: Evidence from ARDL approach. Energy Economics Letters, 7(2), 61-73. https://doi.org/10.18488/journal.82.2020.72.61.73

Musa., K. S., Maijama'a, R., Mohammed, N., \& Adamu, Y. (2020). Assessing the key drivers of energy demand in Nigeria: Application of ARDL approach. Global Scientific Journals, 8(6), 19-40.

Nwani, C. (2017). Causal relationship between crude oil price, energy consumption and carbon dioxide emissions in Ecuador. OPEC Energy Review, 41(3), 201-225.https://doi.org/10.1111/opec.12102

Ogunsakin, S., \& Oloruntuyi, A. O. (2017). Oil price volatility and macroeconomic performance in two top net oil producing countries in Africa. International Economic Research, 8(3), 59-79.

Pesaran, M. H., Shin, Y., Ron, P., \& Smith, R. P. (1999). Pooled mean group estimation of dynamic heterogeneous panels. Journal of the American Statistical Association, 94(446), 621-634. https://doi.org/10.2307/2670182

Pesaran, M. H., Shin, Y., \& Smith, R. J. (2001). Bounds testing approaches to the analysis of level relationships. Journal of

Applied Econometrics, 16(3), 289-326.https://doi.org/10.1002/jae.616.

Philip, P. C., \& Moon, H. R. (1999). Linear regression limit theory for nonstationary panel data. Econometrica, 67(5), 10571111.https://doi.org/10.1111/1468-0262.00070.

Pordan, I. (2013). The effects of whether on stock returns: A comparison between emerging and developed markets (pp. 1-54). Germany: Anchor Academic Publishing. 
Rotimi, M. E., \& Ngalawa, H. (2017). Oil price shocks and economic performance in Africa's oil exporting countries. Acta Universitatis Danubius Economica, 13(5), 169-188. Retrieved from http://journals.univdanubius.ro/index.php/oeconomica/article/view/4234/4424

Salahuddin, M., Alam, K., Ozturk, I., \& Sohag, K. (2017). The effects of electricity consumption, economic growth financial development and foreign direct investment on $\mathrm{CO}_{2}$ emissions in Kuwait. Renewable and Sustainable Energy Reviews, 81( $\left.\mathrm{P} 2\right)$, 2002-2010. https://doi.org/10.1016/j.rser.2017.06.009.

Smahi, A., \& Mohamed, K. S. (2018). Can oil prices forecast the exchange rate? Evidence from Algeria. American Journal of Economics, 8(4), 202-208.https://doi.org/10.5923/j.economics.20180804.03.

Ssali, M. W., Du, J., Mensah, I. A., \& Hongo, D. O. (2019). Investigating the nexus among environmental pollution, economic growth, energy use, and foreign direct investment in 6 selected sub-Saharan African countries. Environmental Science and Pollution Research, 26(11), 11245-11260.

Stock, J. H., \& Warson, M. W. (1993). A simple estimator of cointegrating vectors in higher order integrated system. Econometrica: Journal of the Econometric Society, 61, 783-820.

Sulaiman, C., \& Abdur-Rahim, A. S. (2018). Population growth and $\mathrm{CO}_{2}$ emission in Nigeria: A recursive ARDL approach. Sage Open Access Journal, 8(2), 1-18. https://doi.org/10.1177/2158244018765916

Tiwari, A. K. (2011). A structural VAR analysis of renewable energy consumption, real GDP and $\mathrm{CO}_{2}$ emissions: Evidence from India. Economics Bulletin, 31(2), 1793-1806.

WDI. (2020). World bank's world development indicators. Retrieved from https://data.worldbank.org/indicator. 